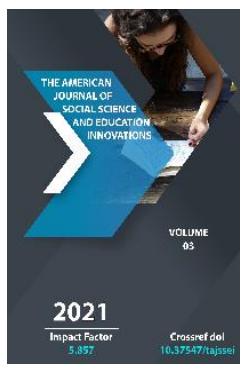

\title{
Educational Importance Of National Idea In Society
}

Usmonov Saidikromkhodja Saidalievich

Researcher At The Tashkent State Pedagogical University Named After Nizami, Uzbekistan

Journal Website:

http://usajournalshub.c

om/index,php/tajssei

Copyright: Original content from this work may be used under the terms of the creative commons attributes 4.0 licence.

\section{ABSTRACT}

Today, at the height of a global pandemic, our need for the national unity and international cooperation seems to grow more acute than ever. As always, education is playing an important role in maintaining the development and rejuvenation of the public life. The national ideology of our country promotes the principles, which also have universal character, and are cherished not only by our people, but also the people of the world. So, we argue that national idea should play, albeit small, a role in the national education. The article contains numerous arguments in favor of this position.

\section{KEYWORDS}

National idea, ideology, value, development, national heritage, inter-religious cooperation, religious tolerance

\section{INTRODUCTION}

The rejuvenation and development of the public life has become one of the main tasks of the state in years of the independence, and the human factor became the primary value in
Uzbekistan. According the first President of the Republic of Uzbekistan: "After the Independence, one of the main tasks of the state police has become the rejuvenation and 
the development of the historical, cultural and traditional heritage of our great ancestors" [1].

The establishment of the international, interreligious cooperation and unity depends in many ways on the implementation of the principles of tolerance, which is one of the international principles of national ideology. In recent years, we witnessed many unwanted processes in the world arena, and their religious component had been a major factor in their development. These events led to many bloodsheds and conflicts many times over, and they illustrate that the establishment of cooperation and coordination among the nations and states of the world is the objective historical need. For this reason, "ensuring security, interethnic harmony and religious tolerance and a well-thought-out, mutually beneficial and practical foreign policy" has been identified as one of the strategic tasks in our country. President of the Republic of Uzbekistan Sh.M.Mirziyoev proposed to adopt a special resolution of the General Assembly entitled "Enlightenment and Religious Tolerance" from the UN rostrum. "This resolution is aimed at promoting tolerance and mutual respect, ensuring religious freedom, protecting the rights of believers and preventing discrimination against them" [2].

\section{MAIN RESULTS AND FINDINGS}

Only a nation with a high level of spirituality can find the strength for a bright independence and a great future. Spiritually developed people and nations value themselves, stand tall, be proud of the past, understand themselves, look to the future with hope, appreciate freedom and independence, and show selflessness for the prosperity of the Motherland.
The national language and national culture, national consciousness, national selfawareness, national feeling, national pride and pride play an important role in the restoration and development of the spirituality of our people.

It is well known that the national idea (ideology) is nourished by the spiritual heritage of the nation and, at the same time, has a positive impact on the development of its spirituality. Now, based on our topic, we will try to answer the question of what constitutes the universal foundations of the national idea.

The meaning of this can be understood only by quoting the following principles established in the national idea and ideology of the Uzbek nation. The Constitution of the Republic of Uzbekistan is based on national and universal values, the principles of democracy; the high spirituality, traditions and customs of our people formed over the centuries are nourished by the immortal heritage of our great ancestors; reflects the ideas of justice and truth, freedom and independence, as well as the beliefs and convictions of our people; serves to ensure the peace of the country, the prosperity of the Motherland and the wellbeing of the people; mobilizes members of society, all segments of the population to create a great future for Uzbekistan; instills in the hearts of every citizen of our country, regardless of nationality, language and religion, a sense of love for the motherland, devotion to the ideas of independence and mutual respect; the diversity of opinions in the hearts and minds of the public is inculcated in an enlightened way, in accordance with the principles of freedom of conscience [3].

The national idea (ideology) has always promoted spiritual knowledge in accordance 
with the requirements and needs of the time, always incorporating issues relevant to each time. The national idea takes into account the needs of the new era on the basis of modern requirements. These are the requirements for a national idea that embodies national interests, needs and corresponds to the spirituality of the people.

In connection with the spiritual needs of the people, the ideology of independence has the following requirements: to embody a system of concepts and feelings, beautiful and vital ideas that have a positive impact on the human heart and mind; to be a unifying force of the nation, people and society, a source of high trust; to be able to assimilate any progressive idea and respond against any evil idea; to be able to propose new means of realizing the interests, goals, which he expresses in accordance with the changes of time and period. On the basis of these, the ideological tasks related to the enrichment and formation of the people's spirituality in the ideology of national independence are set.

These are: the formation of an independent worldview and free thinking; to bring up a person who is free-thinking, free from muteness and cowardice, who lives with confidence in his knowledge and power; to create a spiritual environment that serves to strengthen the will of our people, especially our youth, to strengthen their faith; selfawareness in the minds of our compatriots, devotion to historical memory, preservation of our sacred values, the development of a sense of patriotism; to further enhance the qualities of our people, such as faith, belief, honesty, piety, generosity, honesty, kindness, modesty; formation and development of the idea of "Uzbekistan - the only Motherland" in the minds and hearts of the multinational people of our country [4].

In the first years of independence, the First President of the Republic of Uzbekistan identified the following four main pillars of social development, which will play an important role in strengthening the independence of independent Uzbekistan and ensuring its further development. These are:

- Commitment to universal values;

- Strengthening and developing the spiritual heritage of our people;

- Free expression of one's potential;

- Patriotism [5].

The principles of the national idea (ideology) are intertwined with universal values. The main principles of the national idea are that the national consciousness, national thinking is focused on the formation of national identity, the unification of the nation, the expression of its interests, the formation of national pride, pride and personal responsibility; national heritage, preservation of historical memory, the formation of the spirit of patriotism, nationalism, and humanity in young people; Peaceful coexistence of different nations in our Motherland, the formation in their minds of the idea of "Uzbekistan - the only Motherland"; to promote the formation of the ideas of national security, interethnic harmony and interreligious tolerance among the citizens of our country.

It also represents the common goals of all nations, peoples, religions and strata living in our country, connects the past and future of our people, serves to realize its age-old dreams. On this basis, it shows that the national idea corresponds to the content of universal values in the world, such as 
democratic rights and freedom of conscience, interethnic harmony, interreligious tolerance.

As the President of the Republic of Uzbekistan noted, "Today the times are changing rapidly. Young people are the ones who feel these changes the most. May the youth meet the requirements of their time. But at the same time, don't forget your identity. May the call of who we are and what kind of great people we are, always resonate in their hearts and motivate them to remain true to themselves" [6].

\section{CONCLUSION AND SUGGESTIONS}

The national idea (ideology) recognizes "diversity of ideas", "diversity of ideas, ideologies" from universal principles. These values are a guarantee of development, preservation and strengthening of independence. The national idea (ideology) connects the past of our society with the present and the future, encourages citizens to live and work as partners and solidarity on the basis of the ideas of tolerance for common goals and interests. An individual is aware of the unity of social common interests and goals, as well as the interests and goals of the group. The nation encourages the youth to unite in the spirit of patriotism. This is in line with the goals and interests of the people of Uzbekistan.

The philosophy of tolerance, national harmony and solidarity, respect for national and cultural heritage and the creation of conditions for free development are embodied in the national idea. It also means that it is in harmony with "universal virtuous ideas."

The national idea embodies the noble goals, interests, path of development, beliefs and trust of all nations living in our country, and embodies such qualities as tolerance, nobility, humanity and generosity inherent in our people.

\section{REFERENCES}

1. Karimov I.A. On the path to security and sustainable development. Volume 6 [Хавфсизлик ва барқарорлик тараққиёт йўлидан. 6- жилд] Tashkent, “UZBEKISTAN", 1998. - 125 p.

2. Speech by President of the Republic of Uzbekistan Shavkat Mirziyoyev at the 72nd Session of the United Nations General Assembly

3. The idea of national independence: basic concepts and principles [Миллий истиқлол ғояси: асосий тушунча ва тамойиллар]. - - Tashkent, “UZBEKISTAN", 2000. -46 p.

4. The idea of national independence: basic concepts and principles [Миллий истиқлол ғояси: асосий тушунча ва тамойиллар]. - $\quad$ Tashkent, “UZBEKISTAN", 2000. -46 p.

5. Karimov I.A. Uzbekistan: national independence, economy, politics, ideology. Volume 1 [Ўзбекистон: миллий истиқлол, иқтисод, сиёсат, мафкура. 1-жилд]. - Tashkent, “UZBEKISTAN", 1996. - 364 p.

6. Mirziyoyev Sh. We will resolutely continue our path of national development and raise it to a new level. Works. Volume । [Миллий тараққиёт йўлимизни қатъият билан давом эттириб, янги босқичга кўтарамиз. Асарлар. І-жилд]. Tashkent, “UZBEKISTAN”, 2017. - 486 p. 